\title{
UKRI công bố chính sách xuất bản mở
}

\author{
$\therefore$ sciencevietnam F SciComm (1) August 07, 2021
}

SSHPA (07-08-2021) - Theo Nature đưa tin [1], kể từ tháng 4-2022, tất cả các bài báo khoa học được tài trợ bởi cơ quan tài trợ khoa học quốc gia Anh-UK Research and Innovation hay UKRI—sẽ phải xuất bản mở ngay lập tức. Các bài báo này sẽ phải xuất bản mở hoàn toàn (gold $\mathrm{OA}$ ), hoặc trong trường hợp tạp chí không có chính sách đó thì tác giả sẽ được phép đăng tải bản thảo lên mạng (green $O A)$. Các bài báo này cũng phải có các loại giấy phép tự do để người đọc được quyền tái sử dụng và tái đăng tải. Đáng chú ý, kể từ năm 2024, các loại sách và sách chuyên khảo cũng sẽ phải đăng tải mở trong vòng 12 tháng kể từ khi xuất bản.

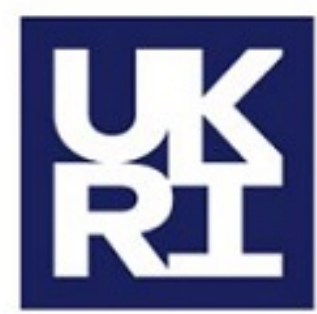

UK Research and Innovation
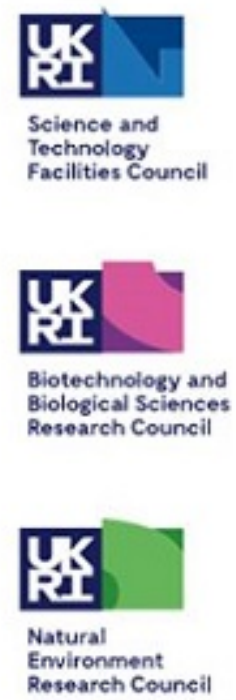
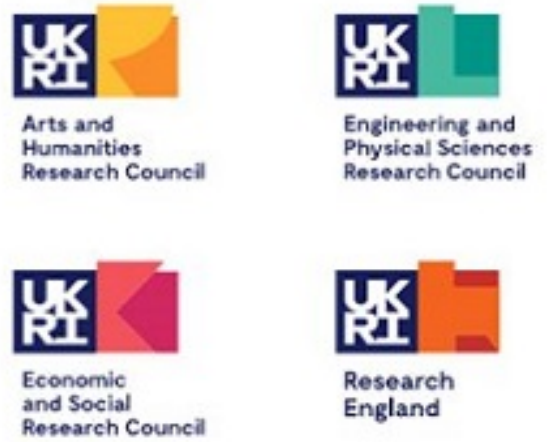

Research Council

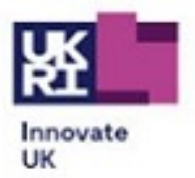

UK

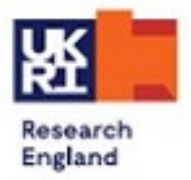

Engineering and Research Council England

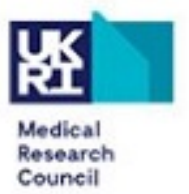

Nguồn: ResearchProfessional News

Hiện tại, vấn đề duy nhất mà UKRI sẽ cần tham khảo thêm để đưa ra quyết định cuối cùng là vấn đề chi trả kinh phí cho các tạp chí lai (hybrid journals) nhưng chưa đạt được thỏa thuận chuyển đổi với các thư viện, trường đại học.

Hiện nay, dự kiến mỗi năm UKRI sẽ hỗ trợ tới 46.7 triệu Bảng Anh để giúp thúc đẩy chính sách khoa học mở. Đây là các bước đi quan trọng để đảm bảo giá trị khoa học và khoa học mở $[2,3]$.

\section{Tài liệu tham khảo:}

[1] Noorden, R. V. (2021). Major UK science funder unveils strict open-access policy. Nature, doi: https://doi.org/10.1038/d41586-021-02148-8

[2] Vuong QH (2017). Open data, open review and open dialogue in making social sciences plausible. Nature: Scientific Data Updates. URL: http://blogs.nature.com /scientificdata/2017/12/12/authors-corner-open-data-open-review-and-opendialogue-in-making-social-sciences-plausible/.

[3] Vuong QH. (2018). The (ir)rational consideration of the cost of science in transition economies. Nature Human Behaviour 2(1): 5. 


\section{Bài liên quan:}

- Voọc chà vá chân nâu - Một trong những loài khỉ đẹp nhất thế giới

- Tại sao biến thể Delta của virus SARS-CoV-2 lại lan nhanh?

- Lấy trứng chọi đá: Liệu tạp chí khoa học có bị thay thế bởi preprint?

- Emerald và F1000 lập nền tảng khoa học mở cho ngành khoa học xã hội

- Thỏa thuận Open Access đầu tiên của hệ thống xuất bản Nature

\section{Ý kiến bạn đọc (0):}

Comment

Gửi bình luận

(c) 2018 - 2021 EASE Vietnam SciComm System. All rights reserved. Powered by Vuong \& Associates. Built to serve the social sciences and humanities. 